\title{
PENERAPAN STRATEGI MARKETING MIX DALAM MENINGKATKAN JUMLAH FUNDING DAN LENDING DI BMT HARAPAN UMMAT SIDOARJO
}

\author{
Indah Nur Anisa ${ }^{1}$ \& Renny Oktafia ${ }^{2}$ \\ ${ }^{1 \& 2}$ Program Studi Perbankan Syariah, Pascasarjana Universitas Muhammadiyah Sidoarjo \\ Email : indahnra09@gmail.com, renny.oktafia@umsida.ac.id
}

\begin{abstract}
ABSTRAK
Pertumbuhan ekonomi nasional pada triwulan I 2020 tercatat sebesar 2,97\% (yoy) terjadi penurunan yang dimana pada triwulan IV 2019 mencapai 4,97\% (yoy). Sedangkan kondisi pertumbuhan ekonomi di Jawa Timur pada triwulan I 2020 sebesar 3,04\% (yoy) dimana lebih rendah dibandingkan pada triwulan IV 2019 yang sebesar 5,54\% (yoy). Dapat dilihat bahwa pertumbuhan ekonomi secara regional maupun nasional mengalami penurunan yang cukup signifikan. Tujuan penelitian ini untuk mengetahui penerapan strategi marketing mix di BMT Harapan Ummat Sidoarjo. Penelitian ini menggunakan metode deskriptif kualitatif dengan menerapkan pendekatan studi kasus yang bertujuan untuk mendapatkan informasi secara langsung dari informan. Teknik pengumpulan data dengan menggunakan observasi, wawancara dan dokumentasi, dimana observasi menggunakan teknik observasi partisipatif. Hasil penelitian ini menunjukkan bahwa penerapan strategi marketing mix di BMT Harapan Ummat sudah baik dan benar akan tetapi ada beberapa strategi yang belum terpenuhi secara utuh sehingga peningkatan jumlah funding dan lending serta pendapatan yang diterima BMT Harapan Ummat tidak meningkat di tiap bulannya.
\end{abstract}

Kata Kunci : Bauran Pemasaran, Funding, Lending.

\begin{abstract}
National economic growth in the first quarter of 2020 was recorded at $2.97 \%$ (yoy), which in the fourth quarter of 2019 reached $4.97 \%$ (yoy). Meanwhile, economic growth in East Java in the first quarter of 2020 was $3.04 \%$ (yoy) which was lower than $5.54 \%$ (yoy) in the fourth quarter of 2019. It can be seen that regional and national economic growth has decreased significantly. The purpose of this research is to find out the application of marketing mix strategy in BMT Harapan Ummat Sidoarjo. This study uses qualitative descriptive methods by applying a case study approach that aims to obtain information directly from informants. Data collection techniques using observations, interviews and documentation, where observations use participatory observation techniques. The results of this study showed that the implementation of marketing mix strategy in BMT Harapan Ummat has been good and correct but there are some strategies that have not been fulfilled completely so that the increase in the amount of funding and lending and revenue received by BMT Harapan Ummat does not increase in each month.
\end{abstract}

Keywords : Marketing Mix, Funding, Lending. 


\section{PENDAHULUAN}

Berdasarkan data (Bank Indonesia, 2020) mengenai Pertumbuhan ekonomi nasional pada triwulan I 2020 tercatat sebesar $2,97 \%$ (yoy) terjadi penurunan yang dimana pada triwulan IV 2019 mencapai $4,97 \%$ (yoy). Sedangkan kondisi pertumbuhan ekonomi di Jawa Timur pada triwulan I 2020 sebesar 3,04\% (yoy) dimana lebih rendah dibandingkan pada triwulan IV 2019 yang sebesar $5,54 \%$ (yoy). Dapat dilihat bahwa pertumbuhan ekonomi secara regional maupun nasional mengalami penurunan yang cukup signifikan. Penurunan ini dipengaruhi oleh menurunnya kinerja konsumsi, net ekspor karena adanya regulasi pembatasan ekonomi dan menurunnya permintaan domestik (Bank Indonesia, 2020)

Pada sektor ekonomi yang terdampak karena adanya covid-19 ini adalah usaha mikro, kecil menenngah (UMKM) dan lembaga keuangan baik syariah maupun konvensional dan lain sebagainya. Kehadiran covid-19 telah membentuk adanya regulasi baru bahwa segala kegiatan harus dilakukan di rumah seperti Work from Home (WFH) dan School from Home (SFH) untuk pencegahan meningkatnya angka covid19. Oleh karena itu, UMKM sangat berdampak karena para pelanggannya sudah jarang bahkan tidak ada lagi yang membeli produknya sehingga pendapatan, modal, dan laba pun terkadang tak didapatnya. Dilihat dari banyaknya jumlah UMKM di Jawa Timur yaitu sebanyak 6,8 juta (Dinas Koperasi, 2018), jika sebagian besar jumlah UMKM terdampak oleh covid-19 maka pertumbuhan ekonomi juga semakin melambat.

Untuk dapat mempertahankan usahanya dimasa pandemi ini, para UMKM mengajukan permodalan kepada pihak lembaga keuangan yang juga terdampak tetapi mendapatkan stimulus dana dari pemerintah untuk disalurkan masyarakat yang mengajukan pembiayaan usaha. Salah satu lembaga keuangan tersebut adalah Baitul Maal wat-Tamwil (BMT) yang dimana berfungsi sebagai lembaga yang bertugas mengembangkan usaha-usaha produktif dan investasi untuk meningkatkan kualitas usaha ekonomi pengusaha kecil dan mikro dengan cara mendorong kegiatan menabung dan pembiayaan usaha serta menerima dan menyalurkan dana zakat, infaq, dan sadaqah (Oktavia, 2014).

Marketing mix merupakan strategi yang di jalankan BMT dan dikaitkan dengan bagaimana BMT menyajikan penawaran produk pada masyarakat, yang merupakan sasaran pasarnya. Marketing mix terdiri dari Product, Price, Promotion, Place, People, Physical Evidence, Process dimana ketujuh variabel itu dapat dikendalikan dan digunakan oleh BMT untuk mempengaruhi pasar sasarannya (Sujono \& Wibowo, 2020). Kegiatan tersebut perlu dikoordinasikan oleh BMT seefektif mungkin dalam melakukan kegiatan pemasaran sehingga ketujuh variabel saling berkesinambungan.

KSPPS BMT Harapan Ummat merupakan salah satu lembaga keuangan syariah yang memberikan solusi atas permasalahan ekonomi masyarakat kecil menengah dengan berbagai macam produk jasa yang dimiliki. Untuk kegiatan pemasaran produk dan jasa, KSPPS BMT Harapan Ummat Sidoarjo memiliki pasar yang cukup potensial karena mempunyai kantor yang cukup strategis karena berdekatan dengan kawasan pasar tradisional. Tetapi KSPPS BMT Harapan Ummat tetap harus mampu untuk melakukan strategi-strategi pemasaran lainnya untuk persaingan ketat saat ini dalam meningkatkan jumlah funding dan lending. 
Dari berbagai pemaparan diatas, permasalahan yang terjadi pada BMT Harapan Ummat di Sidoarjo yaitu penurunan drastis atas jumlah funding pada saat pandemi Covid-19 berlangsung, sehingga BMT harus memiliki strategi yang tepat dalam operasionalnya yaitu penerapan marketing mix. Maka, penulis tertarik untuk meneliti dan mengkaji lebih dalam mengenai Baitul Maal Wat Tamwil (BMT) dan penerapan marketing mix dalam meningkatkan jumlah funding dan lending pada BMT Harapan Ummat Sidoarjo.

\section{TINJAUAN PUSTAKA}

\section{Baitul Maal Wat-Tamwil (BMT)}

Baitul Maal wat Tamwil adalah lembaga keuangan yang memiliki konsep syariah dan lembaga yang memilih menggabungkan konsep maal dan tamwil dalam keseluruhan kegiatannya. Konsep maal lebih mengarah dalam hal menghimpun dan menyalurkan dana untuk zakat, infak dan shadaqah (ZIS) secara produktif (Oktavia, 2014). Sedangkan konsep tamwil lahir untuk kegiatan bisnis produktif yang murni untuk mendapatkan keuntungan dengan sektor masyarakat menengah ke bawah (mikro) yang berlandaskan syariah Islam.

Kehadiran BMT untuk menyerap aspirasi masyarakat muslim di tengah kegelisahan kegiatan ekonomi dengan prinsip riba, sekaligus sebagai support funding untuk mengembangkan kegiatan pemberdayaan usaha kecil dan menengah. Kehadiran lembaga keuangan mikro syariah yang bernama Baitul Maal wat Tamwil (BMT) dirasakan telah membawa manfaat finansial bagi masyarakat, terutama masyarakat kecil yang tidak bankable dan menolak riba, karena berorientasi pada ekonomi kerakyatan. Kehadiran BMT di satu sisi menjalankan misi ekonomi syariah dan di sisi lain mengemban tugas ekonomi kerakyatan dengan meningkatkan ekonomi mikro, itulah sebabnya perkembangan BMT sangat pesat di tengah perkembangan lembaga keuangan mikro konvensional lainnya. (Maudy \& Oktafia, 2020)

\section{Bauran Pemasaran (Marketing Mix)}

Bauran pemasaran adalah perangkat alat pemasaran yang digunakan oleh pemasar untuk membentuk karakteristik jasa yang ditawarkan kepada para sasaran (anggota). Elemen dari bauran pemasaran yaitu terdiri dari $4 \mathrm{P}$ seperti produk, harga, promosi dan distribusi, yang didalamnya akan menentukan tingkat keberhasilan pemasaran dan semua itu ditujukan untuk mendapatkan respon yang diinginkan dari pasar sasaran. Pada perkembangannya yang disesuaikan dengan industri jasa, bauran pemasaran dilakukan penambahan 3P sehingga menjadi 7P (Kotler \& Amstrong, 2008) yakni :

\section{Produk (Product)}

Produk merupakan segala sesuatu yang ditawarkan oleh lembaga ke pasar sasaran untuk diperhatikan, digunakan, dibeli dan dikonsumsi sehingga memuaskan kebutuhan dan keinginan oleh pasar. Strategi produk merupakan elemen terpenting dalam bauran pemasaran, karena pemilihan jenis produk yang akan dipasarkan menentukan kegiatan promosi, penentuan harga dan cara penyalurannya (Wijaya \& Marantika, 2018).

Strategi produk ini akan mempengaruhi strategi lain yang ada dalam bauran pemasaran. Konsumen sangat berhati-hati dalam menentukan keputusan untuk membeli produk mana yang akan dipilih dengan mempertimbangkan kesesuaian kebutuhan, keunggulan produk, pelayanan dan perbandingan harga sebelum memutuskan untuk membeli.

\section{Price (Harga)}

Harga adalah sejumlah uang yang harus dibayar oleh konsumen untuk dapat 
membeli, memiliki, dan memanfaatkan suatu barang atau jasa pada suatu lembaga atau perusahaan. Penentuan nilai harga pada suatu produk merupakan salah satu elemen penting dalam kegiatan pemasaran, karena nilai harga menjadi salah satu faktor dalam keputusan konsumen pada suatu produk yang akan dimanfaatkan, dibeli dan maupun yang akan dimiliki (Selang, 2013). Lembaga keuangan syariah termasuk Baitul Maal Wat-Tamwil (BMT) tidak diperbolehkan adanya bunga atau bunga-berbunga yang memberatkan anggota. Lembaga keuangan syariah diperbolehkan menggunakan prinsip bagi hasil.

\section{Place (Tempat)}

Lokasi merupakan tempat distribusi suatu kegiatan perusahaan termasuk lembaga keuangan syariah. Lokasi juga salah satu faktor penting untuk menarik masyarakat membeli produk atau jasa kita. Suatu lembaga harus menentukan mana lokasi yang dekat dengan pasar sasaran sehingga memudahkan masyarakat dalam bertransaksi. (Ningsih \& Maika, 2020)

\section{Promotion (Promosi)}

Strategi promosi adalah aktivitas pemasaran yang menyebarkan suatu informasi, membujuk, dan mengingatkan kepada masyarakat atas produk jasa dan lembaganya. Tanpa adanya strategi promosi para anggota akan sulit mengenal lembaga Baitul Maal Wat-Tamwil (BMT) dan produk yang dimilikinya. Oleh karena itu, strategi promosi merupakan sarana yang paling ampuh untuk menarik dan mempertahankan anggotanya. Secara umum terdapat empat macam sarana promosi yang dapat digunakan oleh lembaga keuangan dalam mempromosikan produk jasanya yaitu periklanan, promosi penjualan, publisitas, penjualan pribadi (Kasmir, 2005).

\section{People (Sumber Daya Manusia)}

Para pelaku kegiatan dalam BMT selain para karyawan, pengelola, dan pengurus tetapi anggota dan pesaing pun termasuk dalam strategi ini. Anggota juga dapat berpartisipasi dalam memberikan informasi mengenai produk BMT dari mulut ke mulut. Attitude seseorang juga penting dalam strategi ini seperti (Kirom, 2016) :

a. Penampilan pihak marketing harus rapi dan menarik agar masyarakat tertarik untuk menjadi anggota baru.

b. Bahasa tubuh dapat berupa isyarat, ekspresi wajah, pandangan mata, sentuhan, serta postur dan gerakan.

c. Dalam berkomunikasi pihak marketing harus ramah dan suara dalam berbicara harus jelas dan mudah dipahami oleh calon anggota yang ingin mendaftarkan dirinya sehingga tidak ragu untuk menjadi anggota baru lembaga tersebut.

\section{Proses (Process)}

Pengertian proses disini adalah proses bagaimana pelayanan yang diberikan oleh perusahaan kepada konsumennya dengan memberikan informasi mengenai kemudahan penggunaan produk jasa yang telah dipilih. Karena jika dilihat dari sudut pandang konsumen bahwa produk jasa adalah bagaimana proses produk jasa tersebut menghasilkan fungsi (Akbar et al., 2019). Salah satunya diterapkan melalui cara jemput bola dengan mendatangi tempat usaha atau rumah anggota yang tidak sempat datang ke kantor BMT. Sehingga para anggota merasa nyaman ketika melakukan transaksi apapun di lembaga tersebut.

\section{Physical Evidence (Bukti Fisik)}

Bentuk fisik (Bukti/lingkungan fisik) dapat menggambarkan suatu kondisi berupa visi, fasilitas, simbol perusahaan, 
kekayaan perusahaan, kartu nama dan lainnya yang masih berkaitan dengan aktivitas pemasaran. Menurut Kotler (2011) bukti fisik adalah bukti yang dimiliki oleh penyedia jasa yang ditujukan kepada konsumen sebagai usulan nilai tambah konsumen. Hal ini akan semakin memperkuat keberadaan dari jasa tersebut, karena dengan adanya fasilitas pendukung secara fisik,maka pelanggan akan lebih memahami jasa yang ditawarkan tersebut. (Darmawan et al., 2019)

\section{Funding (Penghimpunan Dana)}

Sebagai salah satu lembaga keuangan, dana merupakan aspek terpenting dan utama dalam operasionalnya. Tanpa adanya dana lembaga keuangan tidak dapat bergerak sesuai fungsi intermediasi. Dana merupakan uang tunai maupun aktiva lancar yang dimiliki oleh lembaga keuangan, sumber dana tersebut meliput dana lembaga itu sendiri dan dana dari pihak lain (Sanwani et al., 2017). Penghimpunan dana yang ada pada Baitul Maal Wat-Tamwil (BMT) diperoleh dari produk simpanan, yaitu dana yang yang diperoleh atas kepercayaan anggota kepada pihak BMT untuk disalurkan ke berbagai sektor produktif yang berbentuk pembiayaan.

Produk simpanan yaitu berupa simpanan mudharabah jangka pendek maupun jangka panjang, tabungan wadi'ah dan berbagai macam produk simpanan yang dimiliki setiap BMT (Lisdawami \& Mawardi, 2017). Yang harus dilakukan oleh lembaga keuangan syariah termasuk BMT dalam penghimpunan dana adalah dengan saling percaya antara lembaga dengan masyarakat. Dimana prinsip BMT adalah amanah dalam menghimpun dana, maka diharapkan seluruh pegawai BMT dapat mengelola dana masyarakat dengan amanah sesuai prinsip syariah.

\section{Lending (Penyaluran Dana)}

BMT bukan sekedar lembaga keuangan non bank yang bersifat sosial. Namun, BMT juga sebagai lembaga bisnis dalam rangka memperbaiki perekonomian umat. Sesuai dengan itu, maka dana yang dikumpulkan dari anggota harus disalurkan dalam bentuk pinjaman kepada anggotanya. Pinjaman dana kepada anggota disebut juga pembiayaan. Pembiayaan adalah suatu fasilitas yang diberikan BMT kepada anggotanya untuk menggunakan dana yang telah dikumpulkan oleh BMT dari anggotanya. Orientasi pembiayaan yang di berikan BMT adalah untuk mengembangkan dan meningkatkan pendapatan anggota dan BMT. Sasaran pembiayaan ini adalah semua sektor ekonomi seperti pertanian, industri rumah tangga, perdagangan dan jasa (Sanwani et al., 2017).

Jenis pembiayaan pada umumnya dikembangkan oleh BMT maupun lembaga keuangan Islam lainnya adalah Pertama, pembiayaan murabahah merupakan prinsip yang digunakan adalah sama seperti pembiayaan bai' bithaman ajil, hanya saja proses pengembaliannya dibayarkan pada saat jatuh tempo pengembaliaannya (Sisminawati, 2019). Kedua, pembiayaan mudharabah yaitu suatu perjanjian pembiayaan antara BMT dan anggota dimana BMT menyediakan dana untuk penyediaan modal kerja sedangkan peminjam bertindak sebagai pengelola dana untuk pengembangan usahanya. Jenis usaha yang dimungkinkan untuk diberikan pembiayaan adalah usahausaha kecil seperti pertanian, industri rumah tangga, dan perdagangan (Yaningwati, 2014).

Ketiga, pembiayaan musyarakah adalah pembiayaan dengan akad syirkah, dimana anggota membutuhkan tambahan modal sehingga pihak BMT dan anggota sama-sama sebagai pemilik modal pada suatu usaha. Antara resiko dan 
keuntungan ditanggung bersama sesuai dengan porsi penyertaan (Wiroso, 2011). Keempat, pembiayaan al-Qordhul Hasan, adalah perjanjian pembiayaan tanpa ada margin yaitu pengembalian hanya pokok saja. Hanya beberapa anggota yang dianggap layak yang dapat diberi pinjaman ini yakni kepada anggota yang terdesak dalam melakukan kewajibankewajiban non usaha atau pengusaha yang menginginkan usahanya bangkit kembali tetapi tidak mampu untuk melunasi kewajiban karena penurunan pendapatan dan laba (Sujono \& Wibowo, 2020).

\section{METODE PENELITIAN}

Metode penelitian yang digunakan adalah penelitian deskriptif kualitatif. Metode kualitatif ini sesuai dengan permasalahan yang sedang diteliti yakni penerapan strategi marketing mix di BMT Harapan Ummat Sidoarjo. Pada penelitian kualitatif ini bersifat tidak pasti dan masih terus berkembang (Sugiyono, 2018). Jenis data yang digunakan adalah primer dan sekunder, yang diperoleh dari hasil wawancara secara online serta website BMT.

Lokasi penelitian ini di BMT Harapan Ummat Sidoarjo pada bulan November sampai dengan bulan Januari. Teknik pengumpulan data yang digunakan pada penelitian adalah :

1. Observasi partisipatif pasif, peneliti melakukan observasi dengan mendatangi kantor BMT Harapan Ummat untuk melihat keadaan BMT dan hanya mengamati saja segala aktivitas BMT.

2. Wawancara, menggunakan teknik wawancara secara terstruktur untuk mendapatkan informasi mendalam dari informan.

3. Dokumentasi, data penelitian diperoleh dari wawancara via chat whatsapp dan rekaman.

\section{HASIL DAN PEMBAHASAN}

BMT Harapan Ummat Sidoarjo merupakan koperasi simpan pinjam dan pembiayaan syariah (KSSPS) telah berdiri pada tanggal 25 Februari 2010. BMT Harapan Ummat Sidoarjo sudah 11 tahun berdiri dan turut andil dalam dunia perekonomian Indonesia, terutama perekonomian syariah mikro. Pengalaman, tantangan, rintangan, dan hambatan sudah dilalui oleh BMT Harapan Ummat Sidoarjo dalam menjalankan bisnisnya. Akan tetapi tidak serta-merta membuat BMT tumbang, tetapi menjadi semakin kuat sehingga masih dapat bertahan dan berkembang hingga sekarang. Berdirinya BMT ini diawali oleh keprihatinan para anggota BMT Harapan Ummat akan maraknya praktik rentenir di lingkungan pasar.

Harapan yang besar bagi umat manusia, terutama pengusaha mikro kecil inilah yang menjadi cikal bakal pemberian nama BMT Harapan Ummat Sidoarjo. Pada awalnya, kantor BMT Harapan Ummat Sidoarjo terletak di Pasar Larangan unit III nomor 031. Berawal dari 30 anggota dengan modal yang dikumpulkan sebesar 90 juta. Uang yang diproduktifkan oleh BMT Harapan Ummat sebesar 80 juta karena yang 10 juta untuk menyewa tempat selama 3 tahun. Satu tahun berjalan, BMT Harapan Ummat Sidoarjo membuka kantor kas di Jalan Brigjen Katamso dekat pasar Waru pada awal Mei selama 2 tahun. Kemudian pada tahun 2013 sampai sekarang, BMT Harapan Ummat pindah di Ruko King Safira Residence B2-02 Sepande, Sidoarjo.

\section{Penerapan Marketing Mix Di BMT Harapan Ummat Sidoarjo.}

\section{Product (Produk)}

Produk di BMT Harapan Ummat Sidoarjo menjadi bagian terpenting yang ditawarkan oleh BMT dengan 
memberikan sejumlah nilai pada nggota sesuai kebutuhan mereka. Dalam hal produk BMT Harapan Ummat Sidoarjo menjual produk jasa yang halal, aman, baik mutunya, tidak merugikan, transparan dan paling utama sesuai dengan akad-akad syariah Islam.

BMT Harapan Ummat memiliki beberapa produk simpanan (funding), sebagai berikut :

a. Simpanan Sukarela, simpanan ini sama seperti tabungan pada umumnya tanpa ada batas minimal setoran dan tanpa biaya administrasi. Simpanan ini bisa diambil sewaktu-waktu oleh anggota melalui staff marketing maupun langsung ke kantor. Prinsip yang digunakan adalah akad mudharabah bagi hasil yang dihitung berdasar pada rata-rata saldo simpanan tiap bulannya.

b. Simpanan Berjangka, simpanan yang penyimpananya dalam jangka waktu tertentu yaitu antara 3 bulan, 6 bulan, atau 12 bulan. Besar simpanan minimal Rp 1.000.000. dan simpanan diambil saat jangka waktunya selesai.

c. Simpanan Pelajar, simpanan yang khusus untuk mempersiapkan dana pendidikan. Setoran minimal pada simpanan sebesar Rp. 25.000,00 per bulan dan hanya dapat diambil saat menejelang semester baru atau awal tahun ajaran baru. Produk ini dikhususkan kerjasama antara sekolahsekolah dan BMT dengan akad mudharabah. Untuk saat ini BMT Harapan Ummat sudah bekerjasama dengan dua SDIT dan satu TK.

d. Simpanan Qurban, simpanan yang khusus untuk mempersiapkan dana berQurban. Setoran minimal adalah sebesar Rp. 100.000,00 per bulan dan hanya dapat diambil saat menjelang hari raya Idul Adha dengan menggunakan akad mudharabah.

e. Simpanan Umroh, simpanan khusus untuk mempersiakan ibadah umroh dimana BMT Harapan Ummat Sidoarjo bekerjasama dengan salah satu biro perjalanan umroh. Setoran minimal sebesar Rp. 100.000 per bulan. Apabila simpanan mencapai Rp 3.500 .000 secara otomatis anggota sudah mendapatkan jatah kursi untuk berangkat Umroh dan jika simpanan mencapai Rp 10.000.000 anggota berhak mendapatkan dana talangan (ujroh) dari BMT dan bisa berangkat Umroh ke tanah suci. Akad yang digunakan ialah wadi'ah sedangkan jasa pelunasan ke biro perjalanan akan dikenakan ujroh (fee) tertentu.

f. Simpanan Idul Fitri, simpanan khusus untuk memperisapkan dana hari raya Idul Fitri, dimanan simpanan ini dilakukan secara berjamaah dalam satu rekening yang beranggotakan 25 peserta dan 1 koordinator. Besar setoran hanya Rp. 20.000 setiap minggu dan bebas biaya administrasi. Dapat diambil pada saat dua minggu menjelang lebaran dan peserta mendapat uang tunai simpananya beserta sebuah parsel dari BMT. Dan produk ini menggunakan akad wadi'ah dimana pihak BMT tidak diwajibkan untuk memberikan tambahan bagi hasil.

g. Simpanan SaMaRa, simpanan yang khusus untuk mempersiapkan dana pernikahan dengan setoran minimal Rp. 25.000 per bulan dan hanya dapat 
diambil sebulan menjelang walimah. Akad yang digunakan adalah akad mudharabah.

$\begin{array}{llr}\text { Sedangkan } & \text { untuk produk } \\ \text { pembiayaan, BMT } & \text { Harapan } & \text { Ummat } \\ \text { memiliki produk sebagai berikut : }\end{array}$

a. Musyarakah (Tambah Modal), pembiayaan untuk modal usaha kecil dan menengah dimana BMT Harapan Ummat akan memberikan modal sesuai kebutuhan anggota jika disetujui semua pihak BMT. Selanjutnya anggota mengangsur modal dan memberikan bagi hasil atas usahanya kepada BMT sesuai kesepakatan, kemampuan dan kerelaan anggota.

b. Mudharabah (Usaha Baru), pembiayaan ini diperuntukkan untuk calon anggota yang berencana membuka usaha baru dimana kesluruhan dana usaha akan di support oleh BMT Harapan Ummat selaku investor dan kesepakatan bagi hasil atas usaha tersebut sesuai laporan keuangan tiap bulannya.

c. Murabahah (Beli Barang), sistem akad ini adalah BMT Harapan Ummat yang akan membelikan barang sesuai kebutuhan pesanan anggota jika pengajuan pembiayaan telah disetujui oleh staff marketing dan manajer operasional serta ketua pengurus apabila pengajuan lebih dari Rp. 15.000.000. Kemudian pihak BMT Harapan Ummat menjual barang tersebut kepada anggota dengan harga yang telah disepakati bersama dan anggota wajib mengangsur pembayaran dari pembelian barang tersebut.

d. Ijarah (keperluan lainnya), layanan pembiayaan ini diperuntukkan untuk keperluan jasa seperti biaya kesehatan, sekolah dan lain sebaginya. BMT Harapan Ummat akan membayarkan biaya jasa yang dibutuhkan anggota. Dan bisa juga untuk pembayaran rekening online, seperti PLN, Telkom, PDAM dan lain-lain.

e. Produk HPAI, produk ini adalah salah satu diversifikasi produk dari BMT Harapan Ummat yang mana melayani penjualan obat herbal bermerek HPAI untuk menambah pendapatan.

Selain bergerak di bidang profit, BMT Harapan Ummat Sidoarjo memiliki produk Wakaf Uang yang dikelola secara produktif kemudian hasilnya diambil manfaatnya uuntuk mauquf alaih seperti khitanan massal, makan siang abang becak, pengobatan gratis kajian agama dan pemberdayaan yatim, janda dan dhuafa. Dan telah disahkan oleh Badan Wakaf Indonesia (BWI) sebagai nadzir wakaf uang dengan nomor 3.3.00045.

Dari berbagai produk diatas antara produk simpanan dan pembiayaan, produk yang paling banyak diinginkan oleh calon anggota ialah pembiayaan musyarakah karena pasar sasaran BMT Harapan Ummat adalah pedagang pasar, sehingga akad ini paling cocok untuk para calon anggota untuk penambahan modal dagang mereka.

\section{Price (Harga)}

Harga merupakan sesuatu yang harus di korbankan para konsumen untuk mendapatkan barang yang mereka ingin atau butuhkan. Harga dalam sistem operasional BMT sering disebut bagi hasil atau administrasi. Ada beberapa indikator untuk mengukur variabel harga. 
1. Imbal hasil yang didapat selalu di musyawarahkan dengan anggota.

2. Manfaat yang di dapat sesuai dengan harga yang dikeluarkan.

3. Transparansi dalam perputaran harga jelas dan ditunjukkan secara langsung kepada anggota.

Sesuai dengan wawancara dengan

Bapak Budiman As'ady selaku bagian keuangan BMT Harapan Ummat Sidoarjo bahwa:

"Kalau untuk biaya-biaya itu sudah kami sebutkan saat awal akad dengan anggota dan standar dengan koperasi lainnya." (Budiman As'ady, 05 Januari 2021)

Berikut data nisbah yang dimiliki BMT Harapan Ummat Sidoarjo, yaitu :

Tabel 2. Nisbah Produk Funding dan Lending BMT Harapan Ummat Sidoarjo

\begin{tabular}{cccc}
\hline No & Nama Produk & Anggota & BMT \\
\hline 1 & Simpanan & & \\
& Berjangka & & \\
\cline { 2 - 4 } & 3 bulan & 40 & 60 \\
\cline { 2 - 4 } & 6 bulan & 45 & 50 \\
\hline 2 & 12 bulan & 50 & \\
\hline 3 & Ijarah & $2-2,5 \%$ & \\
\hline 4 & Murabahah & & \\
\hline
\end{tabular}

Sumber : Data Olahan (2020)

\section{Place (Distribusi)}

Lokasi BMT Harapan Ummat sudah strategis, akan tetapi bagi orang baru banyak yang tidak mengetahui tentang keberadaan BMT Harapan Ummat Sidoarjo karena plakat BMT masih dalam perbaikan.

Sesuai dengan pernyataan Asep Sudrajat selaku ketua BMT Harapan Ummat Sidoarjo bahwa :

"BMT Harapan Ummat Sidoarjo memiliki tempat yang strategis yaitu di ruko depan perumahan King Safira Residence dan dekat dengan pasar, tetapi masyarakat yang bukan anggota kami masih banyak yang tidak mengetahuinya karna plakat kami masih dalam perbaikan." (Asep Sudrajat, 04 Januari 2021)

\section{Promotion (Promosi)}

Kegiatan promosi yang dilakukan BMT Harapan Ummat Sidoarjo sudah dijalankan secara teratur, yaitu di mulai dari menyampaikan penjelasan yang spesifik bagi anggota secara langsung.

BMT Harapan Ummat Sidoarjo dalam segi promosinya selalu mengedepankan sifat keberkahan dan sifat transparan dalam pemberian informasi agar selalu terjalin hubungan yang baik antara pihak BMT dan anggotanya. Dan mempromosikan lembaganya dengan membagikan brosur ke pasar dan pedagang yang dekat dengan kantor serta 
melalui website resmi BMT Harapan Ummat.

Sesuai dengan hasil wawancara secara online dengan Bapak Budiman As'ady selaku Bagian Keuangan BMT Harapan Ummat Sidoarjo bahwa :

“ Untuk promosi kita awalnya ke pasar-pasar. Hingga sekarang sudah ada pasar larangan, waru, suko dan sidokerto. Kita juga menawarkan produk kita ke sekolah-sekolah, kalau untuk sekolah masih ada 2 SDIT dan 1 Tk. Kita juga pernah promosi dengan bagi-bagi brosur ke daerah dekat kantor, misal pedagang yang ada di sekitaran sepande dan juga gading fajar." (Budiman As'ady, 02 Januari 2021)

\section{People (Sumber Daya Manusia)}

Pengelola di BMT Harapan Ummat melakukan pengembangan diri melalui pelatihan pelatihan yang diadakan oleh dinas koperasi maupun koperasi lain.

Wawancara online dengan Ibu Ika selaku marketing BMT Harapan Ummat, sebagai berikut :

"Kalau dari sisi SDM, sebenarnya untuk pengelola sendiri tidak ada yang lulusan dari jurusan ekonomi. Oleh karena itu biasanya kami ditunjuk bergiliran untuk mengikuti pelatihan yang diadakan baik oleh dinas koperasi ataupun koperasi lain." (Ika Nur Hikmah, 04 Januari 2021)

\section{Process (Proses)}

Proses yang dilakukan dalam BMT Harapan Ummat adalah dengan cara melakukan interaksi yang baik ramah dan terbuka dengan anggota baik saat di pasar maupun door to door ke rumah warga baik saat melayani anggota, seperti memberikan pelayanan dan memberikan informasi seputar BMT maupun dalam hal sistem kerja dan pemasarannya dalam melakukan prakteknya terkait proses pada pemasaran. Hal tersebut dimulai dengan salam, selalu berkomunikasi dengan efisien dan baik, ramah, sikap sapa, santun dan senyum. Proses seorang pemasar harus menggunakan intelektual, integritas dan tingkat kepekaan yang lebih tinggi pada konsumen. Rasulullah SAW dalam melakukan prakteknya terkait proses pada pemasaran dapat dilihat melalui pelayanan yang santun, ramah serta jelas dalam memberikan informasi (Hidayat \& Anwar, 2019).

BMT Harapan Ummat menggunakan pelayanan jemput bola dalam produk funding dan lendingnya, dimana ketika jatuh tempo atas angsuran anggota maka pihak pengelola seperti marketing mengambil langsung ke pasarpasar atau ke rumah anggota. Sehingga anggota merasakan silaturrahmi yang baik tetap terjalin. Pasar sasaran anggota BMT Harapan Ummat ini ialah pedagang pasar sehingga anggota baru biasanya dibawa oleh anggota lama yang berdagang satu tempat pasar.

\section{Physical Evidence (Bukti Fisik)}

BMT Harapan Ummat Sidoarjo memiliki gedung dengan dua lantai, peralatan yang tertata rapi serta mempunyai letak ruangan ruangan sesuai 
dengan koperasi-koperasi lainnya. Dan peralatan untuk promosi seperti brosur, kuitansi dan lainnya mengenai BMT Harapan Ummat juga sudah menarik sehingga banyak anggota tertarik. Tetapi untuk plakat masih dalam perbaikan untuk menunjukkan bahwa kantor tersebut ialah milik BMT Harapan Ummat.

Dampak Penerapan Marketing Mix Dalam Meningkatkan Jumlah Funding Dan Lending BMT Harapan Ummat Sidoarjo

Penerapan bauran pemasaran (Marketing Mix) yang dilakukan oleh BMT Harapan Ummat Sidoarjo dalam meningkatkan jumlah funding dan lending ini mengalami peningkatan tetapi tidak di tiap bulannya.

\section{Dampak terhadap perkembangan jumlah funding dan Lending di BMT Harapan Ummat.}

Pada bulan April hingga September tahun 2019-2020, jumlah funding dan lending BMT Harapan Ummat tidak menunjukkan mengalami peningkatan tetapi mengalami penurunan dikarenakan pada produk simpanan sedikitnya anggota menyimpan dananya ke BMT dan pada pembiayaan pihak BMT menyeleksi ketat dalam membiayai anggotanya pada saat pandemi ini. Terbukti pada data sebagai berikut :

Tabel 1. Pertumbuhan Jumlah Produk Simpanan dan Pembiayaan BMT Harapan Ummat Sidoarjo Tahun 2019-2020 (dalam Rupiah)

\begin{tabular}{|c|c|c|c|}
\hline \multicolumn{2}{|c|}{ Produk } & 2019 & 2020 \\
\hline \multirow{6}{*}{ Simpanan } & April & 3.392 .196 .528 & 2.730 .212 .906 \\
\hline & Mei & 2.730 .212 .906 & 2.564 .368 .521 \\
\hline & Juni & 2.781 .177 .152 & 2.450 .972 .889 \\
\hline & Juli & 2.766 .215 .865 & 2.357 .473 .755 \\
\hline & Agustus & 2.798 .322 .185 & - \\
\hline & September & 2.852 .758 .595 & - \\
\hline \multirow{6}{*}{ Pembiayaan } & April & 2.109 .111 .894 & 1.618 .059 .791 \\
\hline & Mei & 1.864 .035 .291 & 1.578 .963 .562 \\
\hline & Juni & 1.827 .767 .291 & 1.549 .473 .062 \\
\hline & Juli & 1.759 .458 .391 & 1.484 .516 .633 \\
\hline & Agustus & 1.742 .593 .143 & - \\
\hline & September & 1.844 .987 .041 & - \\
\hline
\end{tabular}

Sumber: Data Primer yang Diolah (2020)

Dari data diatas menunjukkan bahwa perkembangan pada produk simpanan bulan April hingga September tahun 2019 mengalami peningkatan dan penurunan akan di setiap bulannya. Pada bulan Mei tahun 2019 menunjukkan penurunan dari bulan April yakni sebesar
Rp. 661.983.622. Sedangkan pada bulan Mei tahun 2020 juga mengalami penurunan dari bulan sebelumnya sebesar Rp. 165.844.382. Mengalami peningkatan pada bulan September 2019 sebesar Rp. 54.436.410 dari bulan Agustus. 
Pada produk pembiayaan juga menunjukkan perkembangan jumlah produk bulan April hingga September yang mengalami naik turun di tiap bulannya. Sesuai data diatas menunjukkan bahwa pada bulan Mei 2019 mengalami penurunan sebesar Rp. 245.076.603, dan mengalami peningkatan pada bulan September 2019 sebesar Rp. 102.393 .898

\section{Dampak pada Pertumbuhan Jumlah Pendapatan yang Diterima BMT Harapan Ummat Sidoarjo.}

Dari sisi penerimaan pendapatan, BMT Harapan Ummat ini mengalami peningkatan yang cukup signifikan akan tetapi tidak setiap bulannya. Dapat dilihat pada tabel berikut : dari bulan sebelumnya.

Grafik 1. Pertumbuhan Pendapatan yang diterima oleh BMT Harapan Ummat Sidoarjo

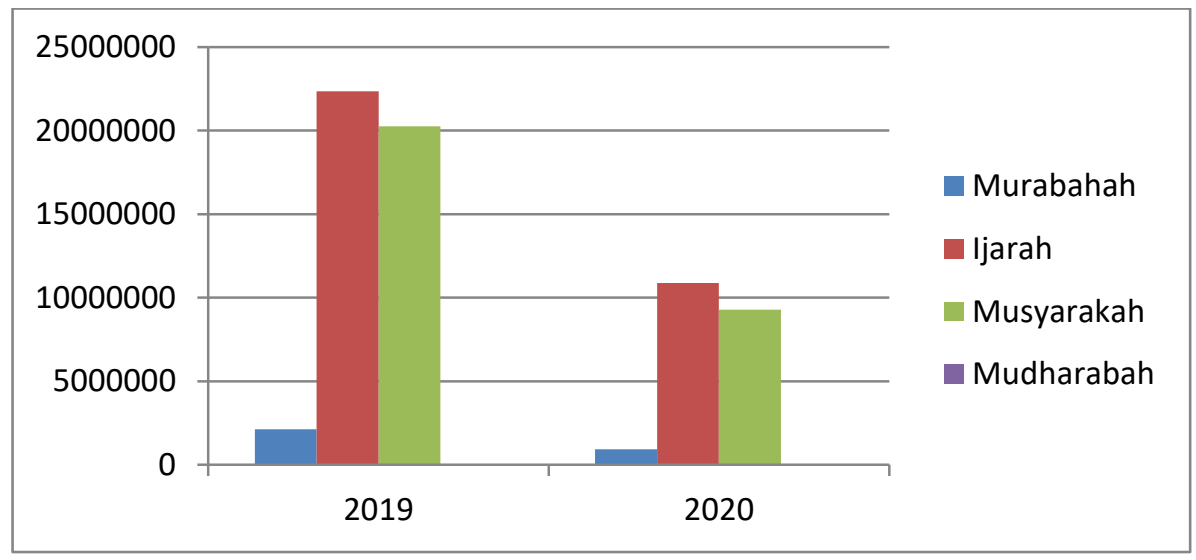

Sumber: Data primer yang diolah (2020)

Dari data diatas menunjukkan bahwa pendapatan yang diterima oleh BMT Harapan Ummat pada tahun 2020 mengalami penurunan yang cukup drastis. Pertama, pendapatan produk murabahah tahun 2019 sebesar Rp. 2.123.700 dimana terdapat penurunan sebesar Rp. 1.181 .700 pada tahun 2020. Kedua, pendapatan produk ijarah tahun 2020 sebsar Rp. 10.885.200 dimana mengalami penurunan dari tahun 2019 yang jumlahnya sebesar Rp. 22.336.565. Ketiga, dan pendapatan produk musyarakah pada tahun 2020 sebesar Rp. 9.284.200 dimana produk ini juga mengalami penurunan sebesar Rp. 10.961.952 dari tahun sebelumnya.

\section{KESIMPULAN}

Berdasarkan hasil penelitian yang dilakukan dan dipaparkan oleh penulis pada bab sebelumnya, peneliti menarik beberapa kesimpulan yakni Pertama,
BMT Harapan Ummat Sidoarjo telah menerapkan beberapa strategi bauran pemasaran (Marketing Mix) dengan baik akan tetapi terdapat beberapa strategi yang belum terpenuhi secara utuh yakni strategi Promotion dan Physical Evidence dimana belum terdapat plakat BMT Harapan Ummat Sidoarjo sehingga masyarakat masih banyak yang belum mengetahui keberadaan BMT Harapan Ummat. Kedua, Jumlah Funding dan Lending bulan April hingga September tahun 2019-2020 di BMT Harapan Ummat ini mengalami peningkatan tetapi tidak di tiap bulannya dan di tahun 2020 setiap bulannya mengalami penurunan diakibatkan adanya covid-19 sehingga sedikitnya anggota menyimpan dananya ke BMT dan pihak BMT Harapan Ummat juga mengurangi dan menyortir dengan ketat dalam penyaluran pembiayaan pada saat pandemi. Ketiga, Dampak dari 
penerapan strategi Marketing Mix di BMT Harapan Ummat ini adalah peningkatan jumlah funding, lending dan peningkatan pendapatan tetapi tidak setiap bulan sehingga BMT Harapan Ummat Sidoarjo perlu menggiatkan lagi para pengelola dan pengurusnya untuk menerapkan strategi Marketing Mix ini dengan maksimal.

\section{DAFTAR PUSTAKA}

Akbar, Y. R., Zain, I., \& Nuraini, P. 2019. Analisis Dimensi Service Marketing Mix Sebagai Pengukur Kepuasan Nasabah Bank Syariah Di Pekanbaru. Jurnal Tabarru': Islamic Banking and Finance, 2(2), p. 1-15.

Bank Indonesia. 2020. Laporan Perekonomian Provinsi Jawa Timur Februari 2020. di kutip dari : https://www.bi.go.id/id/publikasi/kaji an-ekonomiregional/jatim/Pages/LPP-JATIMFEB-2020.aspx

Bank Indonesia. 2020. Pertumbuhan Ekonomi Indonesia Triwulan I 2020 Melambat. di kutip dari : https://www.bi.go.id/id/ruangmedia/siaranpers/Pages/sp_223620.aspx

Darmawan, A., Khasanah, K., \& Rejeki, S. 2019. Penerapan Marketing Mix Terhadap Loyalitas Pelanggan Bank Syariah Mandiri Di Purwokerto Dengan Keputusan Menabung Sebagai Variabel Intervening. Fidusia : Jurnal Keuangan dan Perbankan 2(1), p. 1-13.

Dinas Koperasi. 2018. Data UKM Di Jawa Timur. di kutip dari : http://diskopukm.jatimprov.go.id/inf o/data-ukm

Hidayat, M. A., \& Anwar, Moch Khoirul . 2019. Bauran Pemasaran Pada BMT Mandiri Sejahtera Cabang Kedungpring Dalam Perspektif Etika Bisnis Islam. Jurnal Ekonomi Islam, 2(2), p. 86-96.
Kasmir. 2005. Pemasaran Bank. Prenada Media. Jakarta.

Kirom, C. 2016. Strategi Marketing Mix Baitul Mal Wa Tamwil (BMT) Unit Gabungan Terpadu (UGT) Sidogiri Pasuruan. Maraji' Jurnal Ilmu Keislaman, 3(1), p. 163-181.

Kotler, Philip. 2011. Manajemen Pemasaran Indonesia edisi 1. Salemba Empat. Jakarta.

Kotler, Philip \& Amstrong, G. 2008. Prinsip-Prinsip Pemasaran (VIII). Erlangga. Jakarta,

Lisdawami, I. M., \& Mawardi, I. 2017. Pengembangan Produk Funding KSPPS BMT Amanah Ummah Jawa Timur. Jurnal Ekonomi Syariah Teori Dan Terapan, 4(11). p. 889901.

Maudy, A. L., \& Oktafia, Renny. 2020. Strategi Optimalisasi Penghimpunan Dana Nasabah Bagi Perkuatan Permodalan Di BMT Mawaddah Kantor Cabang Pandaan Pasuruan. Al-Mustashfa: Jurnal Penelitian Hukum Ekonomi Islam, 5(2), p. 171182.

Ningsih, D. D. S., \& Maika, M. R. 2020. Strategi Bauran Pemasaran 4P Dalam Menentukan Sumber Modal Usaha Syariah Pedagang Pasar di Sidoarjo. Jurnal Ilmiah Ekonomi Islam, 6(03), p. 693-702.

Oktavia, R. 2014. Peranan Baitul Maal Wattamwil (BMT) Terhadap Upaya Perbaikan Moral Masyarakat Di Kawasan Dolly Surabaya. AnNisbah, 01(01), p. 119-137.

Sanwani, Herwanti, T., \& Jufri, A. 2017. Strategi penghimpunan dan penyaluran dana pada Baitul Maal wat Tamwil. Al Masraf: Jurnal Lembaga Keuangan Dan Perbankan, 2(1), p. 1-16.

Selang, C. A. 2013. Bauran Pemasaran 
(Marketing Mix) Pengaruhnya Terhadap Loyalitas Konsumen Pada Fresh Mart Bahu Mall Manado. Jurnal Emba, 1(3), p. 71-80.

Sisminawati. 2019. Implementasi Bauran Pemasaran Atas Sosialisasi Produk ZISWAF Pada BMT Hasanah Ponorogo. Tesis pada Institut Agama Islam Negeri (IAIN) Ponorogo.

Sugiyono. 2018. Metode Penelitian Kualitatif, Kuantitatif dan $R \& D$. Alfabeta. Bandung.

Sujono, R. I., \& Wibowo, F. W. 2020. Marketing Mix Dan Tingkat Margin Dalam Pengambilan Keputusan Pembiayaan Pada Nasabah Bank Syariah. EL-Dinar, 8(1), p. 37-51.

Wijaya, E., \& Marantika, P. 2018. Pengaruh Service Marketing Mix Terhadap Keputusan Nasabah Untuk Menabung Pada PT. Bank Mayapada Internasional Tbk. Cabang A. Yani Pekanbaru. Journal of Economic, Business and Accounting (COSTING), 1(2), p. 283-296.

Wiroso. 2011. Produk Perbankan Syariah. LPFE Usakti. Jakarta.

Yaningwati, F. 2014. Analisi Pengaruh Pembiayaan Mudharabah Dan Musyarakah Terhadap Tingkat Profitabilitas (Return On Equity) ( Studi pada Bank Umum Syariah Yang Terdaftar di Bank Indonesia Periode 2009-2012 ). Jurnal Administrasi Bisnis (JAB), 12(1), p. 1-9. 